\title{
EKSPLORASI DATA ARKEOLOGI \\ DI KAWASAN LERENG TIMUR GUNUNG MERAPI KABUPATEN BOYOLALI, JAWA TENGAH
}

\author{
Sugeng Riyanto \\ (Balai Arkeologi Yogyakarta) \\ Email: sugeng.rivanto@arkeologiiawa.com
}

\begin{abstract}
ABSTRAK
Kabupaten Boyolali secara geografis meliputi kawasan lereng timur Gunung Merapi (dan Merbabu). Secara arkeologis kawasan ini sangat "diperhitungkan" sebagai salah satu kawasan yang menyimpan peninggalan berupa data arkeologi dengan rentang masa yang cukup panjang. Di sisi lain, perhatian atas kawasan ini belum sebesar kawasan lereng selatan dan barat yang secara akademis telah menyumbangkan informasi dan pengetahuan akan masa lalu bangsa Indonesia, khususnya dari masa klasik (abad VIII - X M), masa islam (mulai abad XVI M), hingga masa kolonial (sekitar abad XVII - awal abad XX M). Oleh karena itu sungguh tidak berlebihan jika kegiatan penelitian melalui eksplorasi arkeologis di kawasan lereng timur Gunung Merapi ini menjadi momentum akan bangkitnya perhatian terhadap data arkeologi di kawasan ini, demi menyumbangkan informasi dan pengetahuan dalam rangka pembangunan ideologis, pengembangan nilai ilmiah, maupun ancangan untuk penggalian nilai-nilai ekonomik.
\end{abstract}

Kata Kunci: Boyolali, Merapi, arkeologi

\author{
ARCHAEOLOGICAL EXPLORATION \\ IN THE EAST MOUNT SLOPE OF MERAPI \\ BOYOLALI DISTRICT, CENTRAL JAVA
}

\begin{abstract}
Boyolali District geographic area covers the eastem slopes of Mount Merapi (and Merbabu). In the archaeological area is very important as an area that holds relics of archaeological data with a fairly long time span. On the other hand, concern over this region has not been for the region south and west slopes are academically have contributed information and past knowledge of the Indonesian people, especially from the classical period (eighth century - XM), Islamic period (beginning of the sixteenth century $A D$ ), until colonial period (about XVII century - beginning of XX century AD). Therefore it was not excessive if the research activities through archaeological exploration in the eastern slopes of Mount Merapai is a momentum to the rise of attention to archaeological data in the region, to
\end{abstract}


contribute information and knowledge within the framework of ideological development, the development of scientific value, as well as the approaches to extracting value -economic values.

Keywords: Boyolali, Merapi, archaeology

\section{PENDAHULUAN}

Lereng Gunung Merapi menyimpan ratusan peninggalan kuna khususnya berupa bangunan candid an bangunan masa kolonial. Penelitian dan pengembangan sumber daya arkeologi tersebut hingga kini masih terfokus lereng bagian barat dan selatan yang termasuk dalam wilayah Magelang dan Yogyakarta. Sementara itu potensi di lereng timur dan utara, khususnya di wilayah Kabupaten Boyolali belum banyak diteliti dan dimanfaatkan.

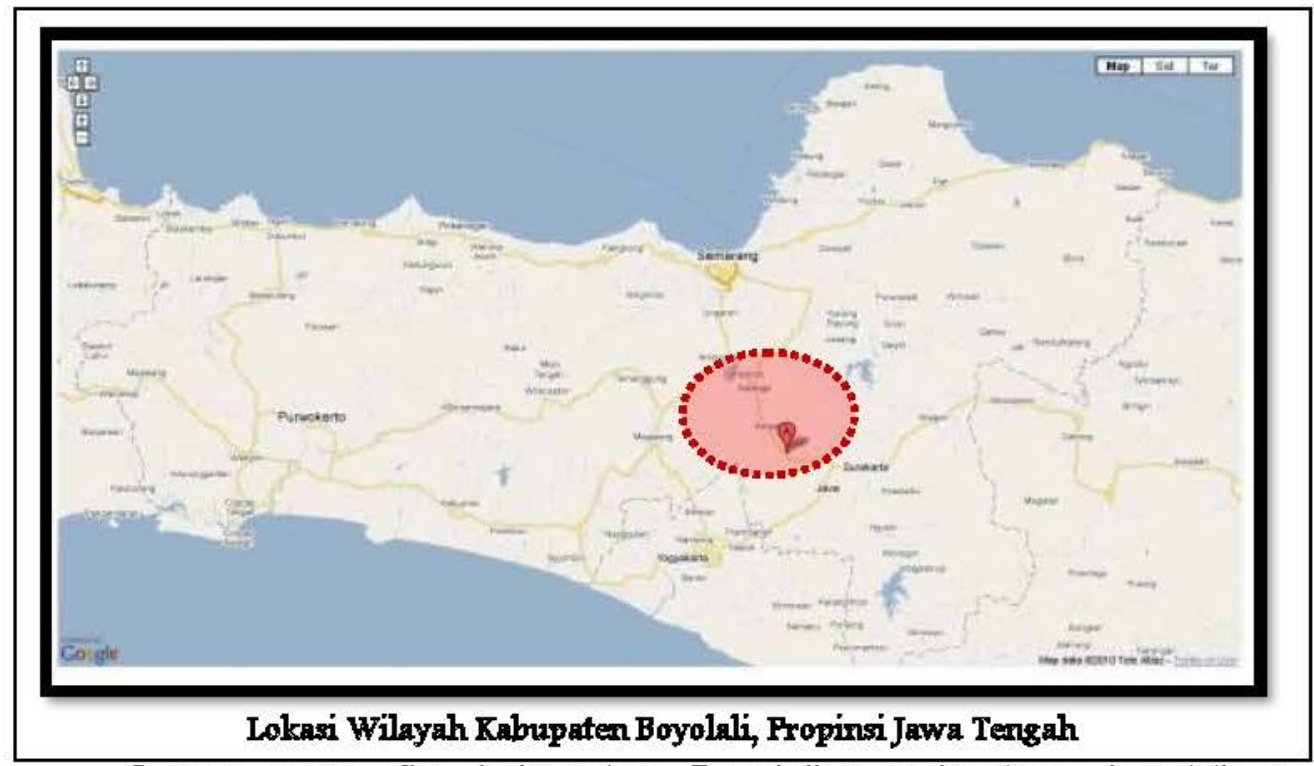

Secara geografis, kabupaten Boyolali membentang barat-timur sepanjang $49 \mathrm{~km}$, dan utara-selatan $54 \mathrm{~km}$. Sebagian besar wilayahnya adalah dataran rendah dan dataran bergelombang dengan perbukitan yang tidak begitu terjal. Bagian barat merupakan daerah pegunungan, dengan puncaknya Gunung Merapi $(2.911 \mathrm{~m})$ dan Gunung Merbabu $(3.141 \mathrm{~m})$, keduanya adalah gunung berapi aktif, bagian utara (perbatasan dengan Kabupaten Grobogan) merupakan daerah perbukitan, bagian dari rangkaian Pegunungan Kendeng. Di bagian utara (perbatasan dengan Kabupaten Sragen) terdapat Waduk Kedungombo.

Di wilayah Kabupaten Boyolali terdapat sejumlah potensi sumberdaya arkeologi antara lain adalah situs Cabean Kunti, situs Sumur Sanga, Candi Sari, dan Candi Lawang. Bangunan-bangunan masa Hindu- 
Budha tersebut diduga berkaitan dengan Kerajaan Mataram Kuna (abad ke8 - $10 \mathrm{M}$ ) seperti halnya candi-candi di wilayah lain seperti Borobudur, Prambanan, Mendut, dan serta situs-situs lain di wilayah Kedu khususnya (Tim Penelitian Balai Arkeologi Yogyakarta, 2007: 1).

Hingga saat ini, perhatian terhadap candi-candi di wilayah Kabupaten Boyolali baru sebatas pendataan dan penyelamatan, khususnya situs Cabean Kunti, situs Sumur Sanga, Candi Sari, dan Candi Lawang. Di sisi lain, di kawasan lereng timur Merapi juga terdapat banyak data arkeologi dari masa yang lebih muda, yaitu masa kolonial. Data tersebut tersebar di beberapa kecamatan dan secara khusus terkonsentrasi di kawasan "kota lama" Boyolali (Riyanto, 2006: 98-102)

Untuk itu diperlukan penelitian untuk mengeksplorasi potensi data arkeologi yang terkandung di kawasan lereng timur Merapi, khususnya di Kabupaten Boyolali. Penelitian eksplorasi tersebut dilakukan melalui:

1) Penjajagan: berupa studi pustaka dan sumber-sumber sekunder

2) Pengumpulan data lapangan: survei, pemetaan, pendokumentasian

3) Pengolahan data: penyusunan data sebaran secara spasial dan identifikasi karakter data

4) Analisis potensi: pemilahan data arkeologi dan situs untuk pengembangan penelitian dan penyusunan kerangka pengelolaan

Tulisan ini adalah paparan hasil eksplorasi tersebut yang meliputi gambaran data spasial, keragaman, dan potensi pengembangan.

\section{DATA SPASIAL}

Hasil eksplorasi meliputi 79 titik potensi data arkeologi yang tersebar di 11 wilayah kecamatan dan terdiri atas potensi situs masa klasik sejumlah 39 , masa islam 13 , dan masa kolonial 27 . Selengkapnya, titik-titik potensi tersebut adalah sebagai berikut (Tim Penelitian Balai Arkeologi Yogyakarta, 2010).

\begin{tabular}{|l|c|c|c|c|l|}
\hline \multicolumn{1}{|c|}{ OBJEK } & $\begin{array}{c}\text { KOORDINAT } \\
\text { (S-E) }\end{array}$ & DPL & KEC. & MASA & PEMANFAATAN \\
\hline $\begin{array}{l}\text { Makam Mbah } \\
\text { Santri }\end{array}$ & $\begin{array}{c}07^{\circ} 27^{\prime} 18,6^{\prime \prime} \\
110^{\circ} 33^{\prime} 42,1^{\prime \prime}\end{array}$ & 635 & Ampel & Islam & $\begin{array}{l}\text { Objek ziarah setiap } \\
\text { malam Jum'at dan } \\
\text { malam Selasa } \\
\text { Kliwon. }\end{array}$ \\
\hline $\begin{array}{l}\text { Makam Syeh } \\
\text { Maulana } \\
\text { Ibrahim } \\
\text { Magribi }\end{array}$ & $\begin{array}{c}07^{\circ} 27^{\prime} 27,2^{\prime \prime} \\
110^{\circ} 29^{\prime} 08,4^{\prime \prime}\end{array}$ & 1.238 & Ampel & Islam & $\begin{array}{l}\text { Objek wisata ziarah } \\
\text { lokal }\end{array}$ \\
\hline $\begin{array}{l}\text { Petirtaan Reco } \\
\text { Klumpit }\end{array}$ & $\begin{array}{c}07^{\circ} 28^{\prime} 18,6^{\prime \prime} \\
110^{\circ} 34^{\prime} 51,2^{\prime \prime}\end{array}$ & 517 & Ampel & Klasik & Pemandian Umum \\
\hline $\begin{array}{l}\text { Kompleks } \\
\text { Makam } \\
\text { Belanda }\end{array}$ & $\begin{array}{c}07^{\circ} 27^{\prime} 25,1^{\prime \prime} \\
110^{\circ} 33^{\prime} 06,1^{\prime \prime}\end{array}$ & 692 & Ampel & Kolonial & Terbengkalai. \\
\hline
\end{tabular}




\begin{tabular}{|c|c|c|c|c|c|}
\hline $\begin{array}{l}\text { Kompleks } \\
\text { Makam Kyai } \\
\text { Ageng } \\
\text { Kebokanigoro }\end{array}$ & $\begin{array}{l}07^{\circ} 33^{\prime} 17,0 " \\
110^{\circ} 41^{\prime} 02,4 "\end{array}$ & 192 & Banyudono & Islam & $\begin{array}{l}\text { Kompleks } \\
\text { pemakaman umum } \\
\text { dan tempat ziarah. }\end{array}$ \\
\hline $\begin{array}{l}\text { Kompleks } \\
\text { Makam Kyai } \\
\text { Ageng } \\
\text { Kebokanigoro }\end{array}$ & $\begin{array}{c}07^{\circ} 33^{\prime} 17,0^{\prime \prime} \\
110^{\circ} 41^{\prime} 02,4 "\end{array}$ & 192 & Banyudono & Islam & Tempat ziarah. \\
\hline $\begin{array}{l}\text { Makam } \\
\text { Pujonggo } \\
\text { R.Ng. } \\
\text { Yosodipuro }\end{array}$ & $\begin{array}{c}07^{\circ} 33^{\prime} 02,7^{\prime \prime} \\
110^{\circ} 40^{\prime} 29,6^{\prime \prime}\end{array}$ & 198 & Banyudono & Islam & Tempat ziarah. \\
\hline $\begin{array}{l}\text { Makam } \\
\text { Pujonggo } \\
\text { R.Ng. } \\
\text { Yosodipuro } \\
\end{array}$ & $\begin{array}{c}07^{\circ} 33^{\prime} 02,7^{\prime \prime} \\
110^{\circ} 40^{\prime} 29,6^{\prime \prime}\end{array}$ & 198 & Banyudono & Islam & Tempat ziarah. \\
\hline $\begin{array}{l}\text { Masjid } \\
\text { Ciptomulyo }\end{array}$ & $\begin{array}{c}07^{\circ} 33^{\prime} 03,2^{\prime \prime} \\
110^{\circ} 40^{\prime} 31,3^{\prime \prime}\end{array}$ & 198 & Banyudono & Islam & $\begin{array}{l}\text { Masjid sebagai } \\
\text { tempat ibadah. }\end{array}$ \\
\hline Umbul Dudo & $\begin{array}{c}07^{\circ} 33^{\prime} 12,5^{\prime \prime} \\
110^{\circ} 40^{\prime} 30,0^{\prime \prime}\end{array}$ & 194 & Banyudono & Islam & Obyek Wisata \\
\hline $\begin{array}{l}\text { Umbul } \\
\text { Gemuling }\end{array}$ & $\begin{array}{c}07^{\circ} 32^{\prime} 16.8^{\prime \prime} \\
110^{\circ} 41^{\prime} 05.8^{\prime \prime}\end{array}$ & 190 & Banyudono & Islam & $\begin{array}{l}\text { Tempat pemandian } \\
\text { dan pengairan }\end{array}$ \\
\hline $\begin{array}{l}\text { Umbul } \\
\text { Ngabean }\end{array}$ & $\begin{array}{c}07^{\circ} 33^{\prime} 11,3^{\prime \prime} \\
110^{\circ} 40^{\prime} 33,2^{\prime \prime}\end{array}$ & 194 & Banyudono & Islam & Obyek wisata \\
\hline $\begin{array}{l}\text { Umbul } \\
\text { Temanten }\end{array}$ & $\begin{array}{c}07^{\circ} 33^{\prime} 11,4^{\prime \prime} \\
110^{\circ} 40^{\prime} 31,0^{\prime \prime}\end{array}$ & 195 & Banyudono & Islam & Obyek wsata \\
\hline $\begin{array}{l}\text { Pesanggrahan } \\
\text { Pracimoharjo }\end{array}$ & $\begin{array}{l}07^{\circ} 31^{\prime} 23,1^{\prime \prime} \\
110^{\circ} 32^{\prime} 23,4^{\prime \prime}\end{array}$ & 794 & Cepogo & Islam & $\begin{array}{l}\text { Terbengkalai, } \\
\text { namun ada bagian } \\
\text { tertentu yang } \\
\text { dimanfaatkan untuk } \\
\text { tempat bersemedi. }\end{array}$ \\
\hline Arca Durga & $\begin{array}{l}07^{0} 31^{\prime} 31,8 " \\
110^{\circ} 30^{\prime} 54.1^{\prime \prime}\end{array}$ & 998 & Cepogo & Klasik & Terbengkelai \\
\hline Batu Cadi & $\begin{array}{l}07^{0} 31^{\prime} 26,3^{\prime \prime} \\
110^{\circ} 31^{\prime} 06.0^{\prime \prime}\end{array}$ & 947 & Cepogo & Klasik & Terbengkelai \\
\hline Batu Candi & $\begin{array}{l}07^{\circ} 31^{\prime} 31,1^{\prime \prime} \\
110^{\circ} 31^{\prime \prime} 18.6^{\prime \prime}\end{array}$ & 925 & Cepogo & Klasik & Terbengkelai \\
\hline Batu Candi & $\begin{array}{l}07^{0} 31^{\prime} 29,6^{\prime \prime} \\
110^{0} 31^{\prime} 17.3^{\prime \prime}\end{array}$ & 931 & Cepogo & Klasik & Terbengkelai \\
\hline Batu Candi & $\begin{array}{l}07^{0} 31^{\prime} 23,7^{\prime \prime} \\
110^{\circ} 31^{\prime} 12.9^{\prime \prime}\end{array}$ & 932 & Cepogo & Klasik & Terbengkelai \\
\hline Candi Lawang & $\begin{array}{c}07^{0} 31^{\prime} 24,1^{\prime \prime} \\
110^{\circ} 31^{\prime} 10,4 "\end{array}$ & 932 & Cepogo & Klasik & Tidak dimanfaatkan \\
\hline Candi Sari & $\begin{array}{l}07^{\circ} 31^{\prime} 23,7^{\prime \prime} \\
110^{\circ} 31 ' 39.8^{\prime \prime}\end{array}$ & 1026 & Cepogo & Klasik & ziarah \\
\hline Lumpang Batu & $\begin{array}{l}07^{0} 31^{\prime} 32,4^{\prime \prime} \\
110^{\circ} 30^{\prime} 54.1^{\prime \prime}\end{array}$ & 998 & Cepogo & Klasik & Terbengkelai \\
\hline $\begin{array}{l}\text { Petirtaan Kunti } \\
1 \text { (Cabean } \\
\text { Kunti) }\end{array}$ & $\begin{array}{l}07030^{\prime} 11,0^{\prime \prime} \\
110032,21,0^{\prime \prime}\end{array}$ & 755 & Cepogo & Klasik & $\begin{array}{l}\text { Mencuci \& mandi } \\
\text { penduduk }\end{array}$ \\
\hline $\begin{array}{l}\text { Petirtaan Kunti } \\
2 \text { (Cabean } \\
\text { Kunti) } \\
\end{array}$ & $\begin{array}{l}07^{0} 30^{\prime} 10,9^{\prime \prime} \\
110^{\circ} 32,20,6^{\prime \prime}\end{array}$ & 756 & Cepogo & Klasik & Sumber air \\
\hline
\end{tabular}




\begin{tabular}{|c|c|c|c|c|c|}
\hline $\begin{array}{l}\text { Petirtaan Kunti } \\
3 \text { (Cabean } \\
\text { Kunti) }\end{array}$ & $\begin{array}{l}07^{\circ} 30^{\prime} 11,5^{\prime \prime} \\
110^{\circ} 32^{\prime} 20,5^{\prime \prime}\end{array}$ & 758 & Cepogo & Klasik & $\begin{array}{l}\text { Mencuci \& mandi } \\
\text { penduduk }\end{array}$ \\
\hline $\begin{array}{l}\text { Petirtaan Kunti } \\
4 \text { (Cabean } \\
\text { Kunti) } \\
\end{array}$ & $\begin{array}{c}07^{\circ} 30^{\prime} 12,6^{\prime \prime} \\
110^{\circ} 32^{\prime} 19,4^{\prime \prime}\end{array}$ & 761 & Cepogo & Klasik & $\begin{array}{l}\text { Mencuci \& mandi } \\
\text { penduduk }\end{array}$ \\
\hline $\begin{array}{l}\text { Petirtaan Kunti } \\
5 \text { (Cabean } \\
\text { Kunti) }\end{array}$ & $\begin{array}{l}07^{\circ} 30^{\prime} 13,2^{\prime \prime} \\
110^{\circ} 32,19,1 "\end{array}$ & 762 & Cepogo & Klasik & $\begin{array}{l}\text { Mencuci \& mandi } \\
\text { penduduk }\end{array}$ \\
\hline $\begin{array}{l}\text { Sumur Kuna } \\
901 \text { (Sumur } \\
\text { Songo) }\end{array}$ & $\begin{array}{c}07^{\circ} 29^{\prime} 55,0^{\prime \prime} \\
110^{\circ} 33^{\prime} 26,4^{\prime \prime}\end{array}$ & 621 & Cepogo & Klasik & - \\
\hline $\begin{array}{l}\text { Sumur Kuna } \\
902 \text { (Sumur } \\
\text { Songo) }\end{array}$ & $\begin{array}{l}07^{\circ} 29^{\prime} 55,3^{\prime \prime} \\
110^{\circ} 33^{\prime} 26,7^{\prime \prime}\end{array}$ & 623 & Cepogo & Klasik & - \\
\hline $\begin{array}{l}\text { Sumur Kuna } \\
903 \text { (Sumur } \\
\text { Songo) }\end{array}$ & $\begin{array}{c}07^{0} 29^{\prime} 53,7^{\prime \prime} \\
110^{0} 33^{\prime} 24,7^{\prime \prime}\end{array}$ & 636 & Cepogo & Klasik & - \\
\hline $\begin{array}{l}\text { Sumur Kuna } \\
904 \text { (Sumur } \\
\text { Songo) }\end{array}$ & $\begin{array}{c}07^{\circ} 29^{\prime} 52,9^{\prime \prime} \\
110^{\circ} 33^{\prime} 24,7^{\prime \prime}\end{array}$ & 634 & Cepogo & Klasik & - \\
\hline Gua Jepang 3 & $\begin{array}{l}07^{\circ} 24^{\prime} 27,2 " 2^{\prime \prime} \\
110^{\circ} 41^{\prime} 26,0^{\prime \prime}\end{array}$ & 296 & Klego & Kolonial & Tidak dimanfaatkan. \\
\hline Gua Jepang 4 & $\begin{array}{l}07^{\circ} 24^{\prime} 26,2 " 26 \\
110^{\circ} 41^{\prime} 25,3 "\end{array}$ & 310 & Klego & Kolonial & Tidak dimanfaatkan. \\
\hline Gua Jepang 5 & $\begin{array}{c}07^{\circ} 24^{\prime} 23,6^{\prime \prime} \\
110^{\circ} 41^{\prime} 24,3^{\prime \prime} \\
\end{array}$ & 316 & Klego & Kolonial & Tidak dimanfaatkan. \\
\hline $\begin{array}{l}\text { Bekas } \\
\text { Benteng } \\
\text { Belanda }\end{array}$ & $\begin{array}{l}07^{\circ} 31^{\prime} 56,4^{\prime \prime} \\
110^{\circ} 36^{\prime} 05,7^{\prime \prime}\end{array}$ & 423 & Kota & Kolonial & $\begin{array}{l}\text { Taman Kota } \\
\text { Pandanaran }\end{array}$ \\
\hline $\begin{array}{l}\text { Gapura } \\
\text { Makam } \\
\text { Belanda }\end{array}$ & $\begin{array}{l}07^{\circ} 31^{\prime} 39,3^{\prime \prime} \\
110^{\circ} 36^{\prime} 07,3^{\prime \prime}\end{array}$ & 440 & Kota & Kolonial & $\begin{array}{l}\text { Gapura } \\
\text { perkampungan }\end{array}$ \\
\hline $\begin{array}{l}\text { Gereja Katolik } \\
\text { Hati Tak } \\
\text { Bernoda Santa } \\
\text { Perawan Maria }\end{array}$ & $\begin{array}{c}07^{\circ} 31^{\prime} 53,2 \prime \\
110^{\circ} 35^{\prime} 56,7^{\prime \prime}\end{array}$ & 435 & Kota & Kolonial & Tempat ibadah \\
\hline $\begin{array}{l}\text { Gedung } \\
\text { Pengadilan }\end{array}$ & $\begin{array}{c}07^{\circ} 31^{\prime} 58,3^{\prime \prime} \\
110^{\circ} 36^{\prime} 03,7^{\prime \prime}\end{array}$ & 427 & Kota & Kolonial & $\begin{array}{l}\text { Kantor Pengadilan } \\
\text { Agama Kabupaten } \\
\text { Boyolali }\end{array}$ \\
\hline $\begin{array}{l}\text { Rumah } \\
\text { Tinggal }\end{array}$ & $\begin{array}{c}07^{\circ} 31^{\prime} 57,0^{\prime \prime} \\
110^{\circ} 36^{\prime} 02,5^{\prime \prime}\end{array}$ & 426 & Kota & Kolonial & $\begin{array}{l}\text { Rumah tinggal dan } \\
\text { warung }\end{array}$ \\
\hline Rumah tinggal & $\begin{array}{l}07^{\circ} 31^{\prime} 59,1^{\prime \prime} \\
110^{\circ} 36^{\prime} 02,1^{\prime \prime}\end{array}$ & 428 & Kota & Kolonial & $\begin{array}{l}\text { Tidak dimanfaatkan } \\
\text { / terbengkalai }\end{array}$ \\
\hline $\begin{array}{l}\text { Rumah } \\
\text { Tinggal }\end{array}$ & $\begin{array}{c}07^{\circ} 31^{\prime} 57,0^{\prime \prime} \\
110^{\circ} 36^{\prime} 02,5^{\prime \prime}\end{array}$ & 426 & Kota & Kolonial & $\begin{array}{l}\text { Rumah dinas } \\
\text { KODIM }\end{array}$ \\
\hline $\begin{array}{l}\text { Rumah } \\
\text { Tinggal }\end{array}$ & $\begin{array}{c}07^{\circ} 31^{\prime} 56,5^{\prime \prime} \\
110^{\circ} 36^{\prime} 02,7^{\prime \prime}\end{array}$ & 426 & Kota & Kolonial & $\begin{array}{l}\text { Rumah dinas } \\
\text { KODIM }\end{array}$ \\
\hline $\begin{array}{l}\text { Rumah } \\
\text { Tinggal }\end{array}$ & $\begin{array}{c}07^{\circ} 31^{\prime} 54^{\prime \prime} \\
110^{\circ} 35^{\prime} 51,7^{\prime \prime}\end{array}$ & 440 & Kota & Kolonial & $\begin{array}{l}\text { Rumah tinggal dan } \\
\text { salon kecantikan } \\
\text { Sriwijaya }\end{array}$ \\
\hline $\begin{array}{l}\text { Rumah } \\
\text { Tinggal }\end{array}$ & $\begin{array}{c}07^{\circ} 31^{\prime} 53,8^{\prime \prime} \\
110^{\circ} 35^{\prime} 52,4 "\end{array}$ & 436 & Kota & Kolonial & $\begin{array}{l}\text { Rumah tinggal dan } \\
\text { praktek dokter }\end{array}$ \\
\hline
\end{tabular}




\begin{tabular}{|c|c|c|c|c|c|}
\hline $\begin{array}{l}\text { Rumah } \\
\text { Tinggal }\end{array}$ & $\begin{array}{c}07^{\circ} 31^{\prime} 53,9^{\prime \prime} \\
110^{\circ} 35^{\prime} 49,0^{\prime \prime}\end{array}$ & 444 & Kota & Kolonial & $\begin{array}{l}\text { Rumah tinggal dan } \\
\text { Kantor Yayasan } \\
\text { Prima Medika }\end{array}$ \\
\hline $\begin{array}{l}\text { Rumah } \\
\text { Tinggal }\end{array}$ & $\begin{array}{c}07^{\circ} 31^{\prime} 53,9^{\prime \prime} \\
110^{\circ} 35^{\prime} 49,0^{\prime \prime}\end{array}$ & 445 & Kota & Kolonial & $\begin{array}{l}\text { Rumah tinggal dan } \\
\text { Salon Rama Shinta }\end{array}$ \\
\hline $\begin{array}{l}\text { Rumah } \\
\text { Tinggal }\end{array}$ & $\begin{array}{c}07^{\circ} 31^{\prime} 53,7^{\prime \prime} \\
110^{\circ} 35^{\prime} 40,9^{\prime \prime}\end{array}$ & 454 & Kota & Kolonial & $\begin{array}{l}\text { Rumah tinggal, } \\
\text { tetapi kosong / tidak } \\
\text { dihuni }\end{array}$ \\
\hline $\begin{array}{l}\text { Rumah } \\
\text { Tinggal }\end{array}$ & $\begin{array}{c}07^{\circ} 31^{\prime} 57,8^{\prime \prime} \\
110^{\circ} 36^{\prime} 00,2^{\prime \prime}\end{array}$ & 435 & Kota & Kolonial & Rumah tinggal \\
\hline $\begin{array}{l}\text { Rumah } \\
\text { Tinggal }\end{array}$ & $\begin{array}{c}07^{\circ} 32^{\prime} 11,7^{\prime \prime} \\
110^{\circ} 36^{\prime} 15,4^{\prime \prime}\end{array}$ & 416 & Kota & Kolonial & $\begin{array}{l}\text { Kantor PKPRI } \\
\text { Kabupaten Boyolali }\end{array}$ \\
\hline $\begin{array}{l}\text { Rumah } \\
\text { Tinggal }\end{array}$ & $\begin{array}{c}07^{\circ} 32^{\prime} 03,1^{\prime \prime} \\
110^{\circ} 36^{\prime} 03,8^{\prime \prime}\end{array}$ & 425 & Kota & Kolonial & $\begin{array}{l}\text { Kantor Bank } \\
\text { Mandiri Syariah }\end{array}$ \\
\hline $\begin{array}{l}\text { Rumah } \\
\text { Tinggal }\end{array}$ & $\begin{array}{c}07^{\circ} 31^{\prime} 49,6^{\prime \prime} \\
110^{\circ} 36^{\prime} 06,7^{\prime \prime}\end{array}$ & 438 & Kota & Kolonial & $\begin{array}{l}\text { Panti Asuhan } \\
\text { PAMARDI UTOMO } \\
\text { Boyolali }\end{array}$ \\
\hline Sekolah & $\begin{array}{l}07^{\circ} 31^{\prime} 57,8^{\prime \prime} \\
110^{\circ} 36^{\prime} 00,2^{\prime \prime}\end{array}$ & 436 & Kota & Kolonial & $\begin{array}{l}\text { Kantor Panitia } \\
\text { Pengawas Pemilu } \\
\text { Kabupaten Boyolali } \\
\text { dan Dinas } \\
\text { Pendidikan, } \\
\text { Pemuda, dan Olah } \\
\text { Raga } \\
\end{array}$ \\
\hline $\begin{array}{l}\text { Umbul } \\
\text { Ngabean }\end{array}$ & $\begin{array}{c}07^{\circ} 33^{\prime} 11,3^{\prime \prime} \\
110^{\circ} 40^{\prime} 33,2^{\prime \prime}\end{array}$ & 194 & Kota & Kolonial & Objek wisata \\
\hline $\begin{array}{l}\text { Umbul } \\
\text { Pengilon }\end{array}$ & $\begin{array}{c}07^{\circ} 29^{\prime} 40,1^{\prime \prime} \\
110^{\circ} 37^{\prime} 15,4^{\prime \prime}\end{array}$ & 367 & Kota & Kolonial & Objek wisata \\
\hline $\begin{array}{l}\text { Arca } \\
\text { Dhyanibuddha }\end{array}$ & $\begin{array}{c}07^{\circ} 32^{\prime} 15,9^{\prime \prime} \\
110^{\circ} 38^{\prime} 01,3^{\prime \prime}\end{array}$ & 311 & Mojosongo & Klasik & $\begin{array}{l}\text { Disimpan di Kantor } \\
\text { Kecamatan } \\
\text { Mojosongo }\end{array}$ \\
\hline $\begin{array}{l}\text { Arca Kuwera } \\
\text { (Slembi 3) }\end{array}$ & $\begin{array}{c}07^{0} 33^{\prime} 48,1^{\prime \prime} \\
110^{\circ} 36^{\prime} 05,4^{\prime \prime}\end{array}$ & 399 & Mojosongo & Klasik & $\begin{array}{l}\text { Disimpan di rumah } \\
\text { penduduk }\end{array}$ \\
\hline $\begin{array}{l}\text { Batu Candi } \\
\text { (Recosari 1) }\end{array}$ & $\begin{array}{c}07^{0} 34^{\prime} 00,8^{\prime \prime} \\
110^{\circ} 36^{\prime} 00,8^{\prime \prime}\end{array}$ & 406 & Mojosongo & Klasik & Terbengkalai \\
\hline $\begin{array}{l}\text { Lumpang Batu } \\
\text { (Karangkidul } \\
\text { 1) }\end{array}$ & $\begin{array}{c}07^{\circ} 33^{\prime} 48,8^{\prime \prime} \\
110^{\circ} 37^{\prime} 01,8^{\prime \prime}\end{array}$ & 352 & Mojosongo & Klasik & Menumbuk \\
\hline $\begin{array}{l}\text { Lumpang Batu } \\
\text { (Karangkidul } \\
\text { 2) }\end{array}$ & $\begin{array}{c}07^{\circ} 33^{\prime} 48,1^{\prime \prime} \\
110^{\circ} 37^{\prime} 01,9^{\prime \prime}\end{array}$ & 351 & Mojosongo & Klasik & $\begin{array}{l}\text { Sudah tidak } \\
\text { dipergunakan lagi }\end{array}$ \\
\hline $\begin{array}{l}\text { Lumpang Batu } \\
\text { (Magersari) }\end{array}$ & $\begin{array}{c}07^{\circ} 33^{\prime} 59,0^{\prime \prime} \\
110^{\circ} 35^{\prime} 59,3^{\prime \prime}\end{array}$ & 405 & Mojosongo & Klasik & $\begin{array}{l}\text { Sudah tidak } \\
\text { dipergunakan lagi }\end{array}$ \\
\hline $\begin{array}{l}\text { Lumpang Batu } \\
\text { (Recosari 2) }\end{array}$ & $\begin{array}{c}07^{\circ} 34^{\prime} 01,6^{\prime \prime} \\
110^{\circ} 36^{\prime} 00,5^{\prime \prime}\end{array}$ & 405 & Mojosongo & Klasik & $\begin{array}{l}\text { Sudah tidak } \\
\text { dipergunakan lagi }\end{array}$ \\
\hline $\begin{array}{l}\text { Lumpang Batu } \\
\text { (Slembi 1) }\end{array}$ & $\begin{array}{c}07^{0} 33^{\prime} 41,2^{\prime \prime} \\
110^{\circ} 36^{\prime} 03,8^{\prime \prime}\end{array}$ & 406 & Mojosongo & Klasik & $\begin{array}{l}\text { Sudah tidak } \\
\text { dipergunakan lagi }\end{array}$ \\
\hline $\begin{array}{l}\text { Lumpang Batu } \\
\text { (Slembi 2) }\end{array}$ & $\begin{array}{c}07^{\circ} 33^{\prime} 42,7^{\prime \prime} \\
110^{\circ} 36^{\prime} 04,3^{\prime \prime}\end{array}$ & 403 & Mojosongo & Klasik & $\begin{array}{l}\text { Sudah tidak } \\
\text { dipergunakan lagi }\end{array}$ \\
\hline $\begin{array}{l}\text { Batu Candi } \\
\text { (Karangrejo 1) }\end{array}$ & $\begin{array}{c}07^{0} 32^{\prime} 14,7^{\prime \prime} \\
110^{\circ} 33^{\prime} 47,3^{\prime \prime}\end{array}$ & 597 & Musuk & Klasik & 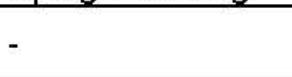 \\
\hline $\begin{array}{l}\text { Batu Candi } \\
\text { (Karangrejo 3) }\end{array}$ & $\begin{array}{c}07^{0} 32^{\prime} 15,2^{\prime \prime} \\
110^{\circ} 33^{\prime} 47,1 "\end{array}$ & 599 & Musuk & Klasik & $\begin{array}{l}\text { talud dan batas } \\
\text { pekarangan }\end{array}$ \\
\hline $\begin{array}{l}\text { Batu Candi } \\
\text { (Kebongulo) }\end{array}$ & $\begin{array}{c}07^{0} 33^{\prime} 23,8^{\prime \prime} \\
110^{\circ} 33^{\prime} 31,3^{\prime \prime}\end{array}$ & 601 & Musuk & Klasik & $\begin{array}{l}\text { talud dan batas } \\
\text { pekarangan }\end{array}$ \\
\hline
\end{tabular}




\begin{tabular}{|l|c|c|c|c|l|}
\hline $\begin{array}{l}\text { Yoni } \\
\text { (Karangrejo 2) }\end{array}$ & $\begin{array}{c}07^{0} 32^{\prime} 15,3^{\prime \prime} \\
110^{\circ} 33^{\prime} 47,7^{\prime \prime}\end{array}$ & 598 & Musuk & Klasik & - \\
\hline $\begin{array}{l}\text { Yoni } \\
\text { (Sukorame) }\end{array}$ & $\begin{array}{c}07^{\circ} 32^{\prime} 42,1^{\prime \prime} \\
110^{\circ} 34^{\prime} 00,8^{\prime \prime}\end{array}$ & 565 & Musuk & Klasik & - \\
\hline Waduk & $\begin{array}{c}07^{\circ} 31^{\prime} 03,3^{\prime \prime} \\
110^{\circ} 43^{\prime} 53,2^{\prime \prime}\end{array}$ & 167 & Ngemplak & Kolonial & $\begin{array}{l}\text { Objek wisata dan } \\
\text { pengairan }\end{array}$ \\
\hline $\begin{array}{l}\text { Makam } \\
\text { Gunung Tugel }\end{array}$ & $\begin{array}{c}07^{\circ} 27^{\prime} 10,6^{\prime \prime} \\
110^{\circ} 39^{\prime} 34,2^{\prime \prime}\end{array}$ & 317 & Sambi. & Islam & Objek wisata ziarah. \\
\hline $\begin{array}{l}\text { Batu Candi } \\
\text { (Candi 2) }\end{array}$ & $\begin{array}{c}07^{\circ} 25^{\prime} 52,8^{\prime \prime} \\
110^{\circ} 39^{\prime} 14,7^{\prime \prime}\end{array}$ & 262 & Simo & Klasik & $\begin{array}{l}\text { untuk upacara } \\
\text { bersih dusun }\end{array}$ \\
\hline Yoni (Candi 1) & $\begin{array}{c}07^{\circ} 26^{\prime} 35,0^{\prime \prime} \\
110^{\circ} 40^{\prime} 59,0^{\prime \prime}\end{array}$ & 214 & Simo & Klasik & $\begin{array}{l}\text { Diberi sesaji dan } \\
\text { dikeramtakan }\end{array}$ \\
\hline $\begin{array}{l}\text { Gua Jepang } \\
\text { (1) }\end{array}$ & $\begin{array}{c}07^{\circ} 24^{\prime} 30,5^{\prime \prime} \\
110^{\circ} 41^{\prime} 26,0^{\prime \prime}\end{array}$ & 289 & Simo & Kolonial & Tidak dimanfaatkan. \\
\hline $\begin{array}{l}\text { Gua Jepang } \\
\text { (2) }\end{array}$ & $\begin{array}{c}07^{\circ} 24^{\prime} 29,0^{\prime \prime} \\
110^{\circ} 41^{\prime} 26,1^{\prime \prime}\end{array}$ & 293 & Simo & Kolonial & Tidak dimanfaatkan \\
\hline $\begin{array}{l}\text { Batu Candi } \\
\text { (Joyudan) }\end{array}$ & $\begin{array}{c}07^{0} 33^{\prime} 49,9^{\prime \prime} \\
110^{\circ} 39^{\prime} 00,3^{\prime \prime}\end{array}$ & 256 & Teras & Klasik & - \\
\hline $\begin{array}{l}\text { Lumpang batu } \\
\text { (Klodran 2) }\end{array}$ & $\begin{array}{c}07^{\circ} 33^{\prime} 42,2^{\prime \prime} \\
110^{\circ} 39^{\prime} 00,8^{\prime \prime}\end{array}$ & 258 & Teras & Klasik & $\begin{array}{l}\text { menumbuk pakan } \\
\text { hewan peliharaan. }\end{array}$ \\
\hline $\begin{array}{l}\text { Lumpang batu } \\
\text { (Klodran) }\end{array}$ & $\begin{array}{c}07^{\circ} 33^{\prime} 38,9^{\prime \prime} \\
110^{\circ} 38^{\prime} 52,5^{\prime \prime}\end{array}$ & 260 & Teras & Klasik & - \\
\hline $\begin{array}{l}\text { Lumpang Batu } \\
\text { (Teras) }\end{array}$ & $\begin{array}{c}07^{\circ} 32^{\prime} 09,5^{\prime \prime} \\
110^{\circ} 39^{\prime} 45,1^{\prime \prime}\end{array}$ & 237 & Teras & Klasik & Menumbuk kopi \\
\hline $\begin{array}{l}\text { Yoni } \\
\text { (Plumutan) }\end{array}$ & $\begin{array}{c}07^{\circ} 33^{\prime} 15,1^{\prime \prime} \\
110^{\circ} 40^{\prime} 17,9^{\prime \prime}\end{array}$ & 204 & Teras & Klasik & - \\
\hline
\end{tabular}

Secara visual, sebaran data hasil eksplorasi data arkeologi di Kabupaten Boyolali adalah sebagai berikut.

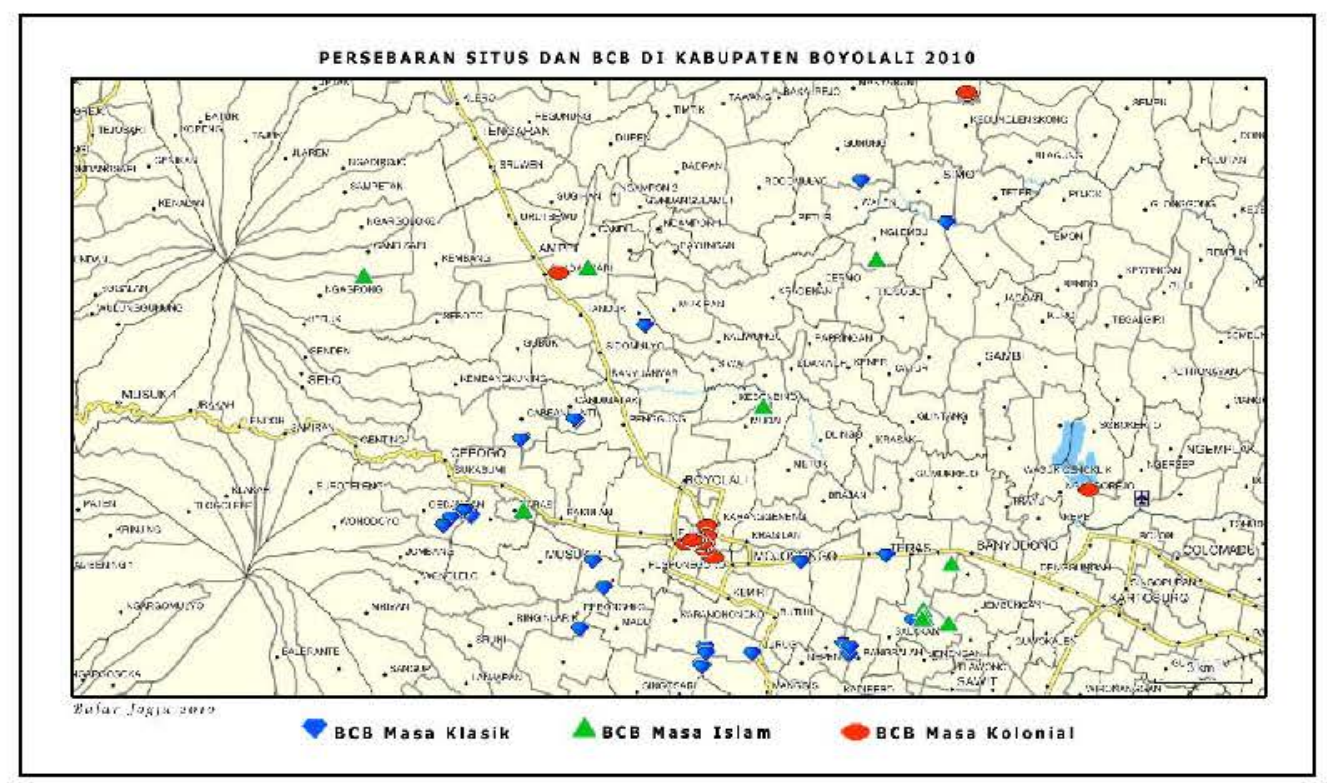




\section{KERAGAMAN DATA ARKEOLOGI}

Karakter data arkeologi hasil eksplorasi menunjukkan tingkat keragaman yang cukup tinggi, khususnya dalam kerangka kategori objeknya. Karakter ini dapat diurai berdasarkan masanya yang meliputi masa klasik, masa islam, dan masa kolonial (Tim Penelitian Balai Arkeologi Yogyakarta, 2010).

\section{Keragaman dan Karakter Data Arkeologi Masa Klasik}

Karakter data arkeologi masa klasik meliputi kategori objek berupa arca, batu candi, candi, lumpang, petirtaan, sumur, dan yoni. Objek dengan kategori arca meliputi 3 situs, yaitu:

\begin{tabular}{|c|c|c|c|}
\hline OBJEK & ELEVASI & KECAMATAN & MASA \\
\hline Arca Durga & 998 & Cepogo & Klasik \\
\hline Arca Dhyanibuddha & 311 & Mojosongo & Klasik \\
\hline Arca Kuwera (Slembi 3) & 399 & Mojosongo & Klasik \\
\hline
\end{tabular}

Objek dengan kategori batu candi ada di 10 titik potensi yaitu:

\begin{tabular}{|c|c|c|c|}
\hline OBJEK & ELEVASI & KECAMATAN & MASA \\
\hline Batu Cadi & 947 & Cepogo & Klasik \\
\hline Batu Candi & 925 & Cepogo & Klasik \\
\hline Batu Candi & 931 & Cepogo & Klasik \\
\hline Batu Candi & 932 & Cepogo & Klasik \\
\hline Batu Candi (Recosari 1) & 406 & Mojosongo & Klasik \\
\hline Batu Candi (Karangrejo 1) & 597 & Musuk & Klasik \\
\hline Batu Candi (Karangrejo 3) & 599 & Musuk & Klasik \\
\hline Batu Candi (Kebongulo) & 601 & Musuk & Klasik \\
\hline Batu Candi (Candi 2) & 262 & Simo & Klasik \\
\hline Batu Candi (Joyudan) & 256 & Teras & Klasik \\
\hline
\end{tabular}

Sementara itu, objek data arkeologi yang termasuk kategori candi meliputi 2 lokasi, yaitu Candi Lawang (932 dpl) dan Candi Sari (1026 dpl). Kedua titik potensi ini secara administrasi termasuk di dalam wilayah Kecamatan Cepogo.

Salah satu data arkeologi masa klasik yang ditemukan adalah lumpang batu, dan titik potensi yang termasuk dalam kategori ini meliputi 10 lokasi, yaitu:

\begin{tabular}{|c|c|c|c|}
\hline OBJEK & ELEVASI & KECAMATAN & MASA \\
\hline Lumpang Batu & 998 & Cepogo & Klasik \\
\hline $\begin{array}{c}\text { Lumpang Batu (Karangkidul } \\
\text { 1) }\end{array}$ & 352 & Mojosongo & Klasik \\
\hline $\begin{array}{c}\text { Lumpang Batu (Karangkidul } \\
\text { 2) }\end{array}$ & 351 & Mojosongo & Klasik \\
\hline Lumpang Batu (Magersari) & 405 & Mojosongo & Klasik \\
\hline Lumpang Batu (Recosari 2) & 405 & Mojosongo & Klasik \\
\hline
\end{tabular}




\begin{tabular}{|c|c|c|c|}
\hline Lumpang Batu (Slembi 1) & 406 & Mojosongo & Klasik \\
\hline Lumpang Batu (Slembi 2) & 403 & Mojosongo & Klasik \\
\hline Lumpang batu (Klodran 2) & 258 & Teras & Klasik \\
\hline Lumpang batu (Klodran) & 260 & Teras & Klasik \\
\hline Lumpang Batu (Teras) & 237 & Teras & Klasik \\
\hline
\end{tabular}

Data arkeologi dalam kategori petirtaan yang berhasil direkam meliputi 6 lokasi, yaitu Petirtaan Reco Klumpit (517 dpl) di Kecamatan Ampel dan 5 lainnya merupakan situs petirtaan yang berada dalam kawasan situs Cabean Kunti $(755$ - $762 \mathrm{dpl})$ yang berada di Kecamatan Cepogo. Selain petirtaan, situs dan $\mathrm{BCB}$ berupa bangunan air yang termasuk dalam ketegori sumur meliputi 4 buah sumur batu yang berada di dalam kawasan situs Sumur Songo (9) (621 - 636 dpl) di Kecamatan Cepogo. Meskipun kawasan situs ini bernama Sumur 9, namun dalam survei baru berhasil direkam sejumlah 4 buah.

Data arkeologi kategori lainnya adalah yoni. Karakter situs dengan kategori ini meliputi 4 titik potensi yang tersebar dalam 3 wilayah kecamatan. Keempat yoni tersebut adalah: Yoni Karangrejo (598 dpl) dan Yoni Sukorame ( $565 \mathrm{dpl}$ ) yang berada di Kecamatan Musuk; Yoni Candi1 (214 dpl) di Kecamatan Simo; dan Yoni Plumutan (204 dpl) di Kecamatan Teras.

\section{Keragaman dan Karakter Data Arkeologi Masa Islam}

Keragaman data dan karakter data arkeologi masa Islam yang berhasil direkam meliputi: kategori makam, mesjid, pesanggrahan, dan umbul. Sebaran keragaman dan karakter yang termasuk kategori makam adalah:

\begin{tabular}{|c|c|c|c|}
\hline OBJEK & ELEVASI & KECAMATAN & MASA \\
\hline Makam Mbah Santri & 635 & Ampel & Islam \\
\hline $\begin{array}{c}\text { Makam Syeh Maulana Ibrahim } \\
\text { Magribi }\end{array}$ & 1238 & Ampel & Islam \\
\hline $\begin{array}{c}\text { Kompleks Makam Kyai Ageng } \\
\text { Kebokanigoro }\end{array}$ & 192 & Banyudono & Islam \\
\hline $\begin{array}{c}\text { Makam Pujonggo R.Ng. } \\
\text { Yosodipuro }\end{array}$ & 198 & Banyudono & Islam \\
\hline Makam Gunung Tugel & 317 & Sambi. & Islam \\
\hline
\end{tabular}

Data dengan kategori mesjid yang berhasil direkam hanya 1 titik, yaitu Mesjid Ciptomulyo (198 dpl) yang berada di Kecamatan Banyudono. Demikian pula dengan data dengan kategori pesanggrahan juga baru 1 lokasi situs yang berhasil direkam, yaitu Pesanggrahan Pracimoharjo (794 dpl) di Kecamatan Cepogo. Sementara itu, data arkeologi masa Islam berkategori umbul meliputi 4 lokasi yang semuanya berada di wilayah 
Kecamatan Banyudono, yaitu: Umbul Dudo (194 dpl), Umbul Gemuling (190 dpl), Umbul Ngabean (194 dpl), dan Umbul Temanten (195 dpl).

\section{Keragaman dan Karakter Data Arkeologi Masa Kolonial}

Ragam serta karakter data arkeologi masa kolonial meliputi kategori: benteng, gereja, gua, kantor, makam, rumah, sekolah, umbul, dan waduk. Kategori benteng adalah lokasi bekas benteng yang sekarang menjadi taman kota di kota Boyolali (423 dpl). Data arkeologi kategori gereja adalah Gereja Katolik Hati Tak Bernoda Santa Perawan Maria (435 dpl) yang berada di kota Boyolali.

Sementara itu kategori gua meliputi:

\begin{tabular}{|c|c|c|c|}
\hline OBJEK & ELEVASI & KECAMATAN & MASA \\
\hline Gua Jepang 3 & 296 & Klego & Kolonial \\
\hline Gua Jepang 4 & 310 & Klego & Kolonial \\
\hline Gua Jepang 5 & 316 & Klego & Kolonial \\
\hline Gua Jepang (1) & 289 & Simo & Kolonial \\
\hline Gua Jepang (2) & 293 & Simo & Kolonial \\
\hline
\end{tabular}

Data arkeologi masa kolonial juga meliputi kategori kantor, yaitu bekas gedung pengadilan $(427 \mathrm{dpl})$ di kota Boyolali yang sekarang menjadi Kantor Pengadilan Agama Kabupaten Boyolali. Sementara itu kategori makam meliputi 2 titik potensi yaitu kompleks makam Belanda (692 dpl) di Kecamatan Ampel dan sebuah gapura makam Belanda (mementomori) (440 dpl) di kota Boyolali.

Kawasan kota Boyolali sebenarnya menyimpan data arkeologi dari masa kolonial yang cukup banyak, beragam, dan penting sebagaimana tampak pada berbagai tinggalan yang masih ada hingga sekarang. Salah satu tinggalan tersebut berupa rumah-rumah kuna bergaya Eropa dan Indies, antara lain adalah:

\begin{tabular}{|c|c|c|c|}
\hline OBJEK & ELEVASI & KEC & SEKARANG \\
\hline Rumah Tinggal & 426 & Kota & Rumah tinggal dan warung \\
\hline Rumah tinggal & 428 & Kota & Tidak dimanfaatkan / terbengkalai \\
\hline Rumah Tinggal & 426 & Kota & Rumah dinas KODIM \\
\hline Rumah Tinggal & 426 & Kota & Rumah dinas KODIM \\
\hline Rumah Tinggal & 440 & Kota & $\begin{array}{c}\text { Rumah tinggal dan salon kecantikan } \\
\text { Sriwijaya }\end{array}$ \\
\hline Rumah Tinggal & 436 & Kota & Rumah tinggal dan praktek dokter \\
\hline Rumah Tinggal & 444 & Kota & $\begin{array}{c}\text { Rumah tinggal dan Kantor Yayasan } \\
\text { Prima Medika }\end{array}$ \\
\hline Rumah Tinggal & 445 & Kota & $\begin{array}{c}\text { Rumah tinggal dan Salon Rama } \\
\text { Shinta }\end{array}$ \\
\hline Rumah Tinggal & 454 & Kota & $\begin{array}{c}\text { Rumah tinggal, tetapi kosong / tidak } \\
\text { dihuni }\end{array}$ \\
\hline Rumah Tinggal & 435 & Kota & Rumah tinggal \\
\hline
\end{tabular}




\begin{tabular}{|l|c|c|c|}
\hline Rumah Tinggal & 416 & Kota & Kantor PKPRI Kabupaten Boyolali \\
\hline Rumah Tinggal & 425 & Kota & Kantor Bank Mandiri Syariah \\
\hline Rumah Tinggal & 438 & Kota & $\begin{array}{c}\text { Panti Asuhan PAMARDI UTOMO } \\
\text { Boyolali }\end{array}$ \\
\hline
\end{tabular}

Tinggalan masa kolonial di Boyolali yang termasuk kategori sekolah adalah sebuah gedung bergaya Eropa $(436 \mathrm{dpl})$ di Kota Boyolali yang sekarang menjadi Kantor Panitia Pengawas Pemilu Kabupaten Boyolali dan Dinas Pendidikan, Pemuda, dan Olah Raga. Data arkeologi dengan kategori umbul juga terdapat dalam masa kolonial berupa dua buah umbul yang keduanya berada di Kota Boyolali, yaitu Umbul Pengilon ( $194 \mathrm{dpl}$ ) dan Umbul Ngabean (367 dpl). Sementara itu, di Kecamatan Ngemplak terdapat sebuah waduk yang merupakan peninggalan masa kolonial, yaitu Waduk Cengklik (167 dpl).

\section{Potensi Pengembangan}

Potensi pengembangan data arkeologi di Kabupaten Baoyolali, setidaknya meliputi dua gejala, yaitu 1) gejala pemanfaatan - pengelolaan, dan 2) gejala potensi akademik.

\section{A. Gejala Pemanfaatan-Pengelolaan}

Gejala pemanfaatan - pengelolaan data arkeologi sebagaimana dipaparkan dalam tabel data spasial menunjukkan gejala yang sangat beragam, yaitu sebagai alat rumah tangga, gapura, kantor, pemakaman, pemandian (sumber air), taman, tempat ibadah, tempat tinggal, wisata, dan ziarah. Namun demikian tidak sedikit data arkeologi yang sebenarnya memiliki nilai intrisik tinggi namun tidak ada penanganan lanjutan dan bahkan terbengkelai tanpa ada perhatian khusus.

Data arkeologi yang dimanfaatkan sebagai alat rumah tangga, khususnya yang digunakan sebagai alat menumbuk adalah tiga buah lumpang, yaitu untuk menumbuk kopi (Teras, Kecamatan Teras), pakan ternak (Klodran 2, Kecamatan Teras), serta menumbuk lainnya (Karangkidul 1, Kecamatan Mojosongo). Data arkeologi yang dimanfaatkan sebagai gapura permukiman adalah bekas gapura makam Belanda di Kota Boyolali yang dikenal dengan Gapura Mementomori. Di Kota Boyolali, terdapat dua rumah kuna yang sekarang digunakan sebagai kantor, serta sebuah gedung sekolah kuna dan sebuah gedung bekas Kantor Pengadilan Belanda yang juga digunakan sebagai kantor. Sementara itu, kompleks makam kuna di situs Kompleks Makam Kyai Ageng Kebokanigoro (Kecamatan Banyudono) saat ini dimanfaatkan sebagai area pemakaman umum.

Data arkeologi yang terkait dengan tata air beberapa di antaranya digunakan sebagai sumber air atau sebagai pemandian umum, yaitu: 


\begin{tabular}{|c|c|c|c|}
\hline OBJEK & ELEVASI & KEC & MASA \\
\hline Petirtaan Reco Klumpit & 517 & Ampel & Klasik \\
\hline Umbul Gemuling & 190 & Banyudono & Islam \\
\hline Petirtaan Kunti 1 (Cabean Kunti) & 755 & Cepogo & Klasik \\
\hline Petirtaan Kunti 2 (Cabean Kunti) & 756 & Cepogo & Klasik \\
\hline Petirtaan Kunti 3 (Cabean Kunti) & 758 & Cepogo & Klasik \\
\hline Petirtaan Kunti 4 (Cabean Kunti) & 761 & Cepogo & Klasik \\
\hline Petirtaan Kunti 5 (Cabean Kunti) & 762 & Cepogo & Klasik \\
\hline
\end{tabular}

Data arkeologi masa kolonial di Kota Boyolali ternyata pada umumnya dimanfaatkan sebagai tempat ibadah, taman, serta rumah tinggal, sebagaimana tampak pada table berikut ini.

\begin{tabular}{|c|c|c|c|c|}
\hline OBJEK & ELEVASI & KEC & MASA & PEMANFAATAN \\
\hline $\begin{array}{c}\text { Masjid } \\
\text { Ciptomulyo }\end{array}$ & 198 & Banyudono & Islam & tempat ibadah. \\
\hline $\begin{array}{c}\text { Bekas Benteng } \\
\text { Belanda } \\
\end{array}$ & 423 & Kota & Kolonial & $\begin{array}{l}\text { Taman Kota } \\
\text { Pandanaran } \\
\end{array}$ \\
\hline $\begin{array}{c}\text { Gereja Katolik } \\
\text { Hati Tak } \\
\text { Bernoda Santa } \\
\text { Perawan Maria }\end{array}$ & 435 & Kota & Kolonial & tempat ibadah \\
\hline Rumah Tinggal & 426 & Kota & Kolonial & $\begin{array}{l}\text { Rumah tinggal dan } \\
\text { warung }\end{array}$ \\
\hline Rumah Tinggal & 426 & Kota & Kolonial & $\begin{array}{c}\text { Rumah dinas } \\
\text { KODIM }\end{array}$ \\
\hline Rumah Tinggal & 426 & Kota & Kolonial & $\begin{array}{c}\text { Rumah dinas } \\
\text { KODIM }\end{array}$ \\
\hline Rumah Tinggal & 440 & Kota & Kolonial & $\begin{array}{c}\text { Rumah tinggal dan } \\
\text { salon kecantikan } \\
\text { Sriwijaya } \\
\end{array}$ \\
\hline Rumah Tinggal & 436 & Kota & Kolonial & $\begin{array}{l}\text { Rumah tinggal dan } \\
\text { praktek dokter }\end{array}$ \\
\hline Rumah Tinggal & 444 & Kota & Kolonial & $\begin{array}{l}\text { Rumah tinggal dan } \\
\text { Kantor Yayasan } \\
\text { Prima Medika }\end{array}$ \\
\hline Rumah Tinggal & 445 & Kota & Kolonial & $\begin{array}{l}\text { Rumah tinggal dan } \\
\text { Salon Rama Shinta }\end{array}$ \\
\hline Rumah Tinggal & 435 & Kota & Kolonial & Rumah tinggal \\
\hline Rumah Tinggal & 438 & Kota & Kolonial & $\begin{array}{c}\text { Panti Asuhan } \\
\text { PAMARDI UTOMO } \\
\text { Boyolali }\end{array}$ \\
\hline
\end{tabular}

Data arkeologi yang dimanfaatkan dan dikelola sebagai tempat ziarah dan objek wisata adalah: 


\begin{tabular}{|c|c|c|c|c|}
\hline OBJEK & ELEV & KEC & MASA & PEMANFAATAN \\
\hline Makam Mbah Santri & 635 & Ampel & Islam & $\begin{array}{c}\text { Objek ziarah setiap } \\
\text { malam Jumat dan } \\
\text { malam Selasa } \\
\text { Kliwon. }\end{array}$ \\
\hline $\begin{array}{c}\text { Makam Syeh } \\
\text { Maulana Ibrahim } \\
\text { Magribi }\end{array}$ & 1238 & Ampel & Islam & $\begin{array}{c}\text { Objek wisata ziarah } \\
\text { lokal }\end{array}$ \\
\hline $\begin{array}{c}\text { Kompleks Makam } \\
\text { Kyai Ageng } \\
\text { Kebokanigoro }\end{array}$ & 192 & Banyudono & Islam & Tempat ziarah. \\
\hline $\begin{array}{c}\text { Makam Pujonggo } \\
\text { R.Ng. Yosodipuro }\end{array}$ & 198 & Banyudono & Islam & Tempat ziarah. \\
\hline $\begin{array}{c}\text { Makam Pujonggo } \\
\text { R.Ng. Yosodipuro }\end{array}$ & 198 & Banyudono & Islam & Tempat ziarah. \\
\hline Umbul Dudo & 194 & Banyudono & Islam & Obyek wisata \\
\hline Umbul Ngabean & 194 & Banyudono & Islam & Obyek wisata \\
\hline Umbul Temanten & 195 & Banyudono & Islam & Obyek wsata \\
\hline Candi Sari & 1026 & Cepogo & Klasik & Tempat ziarah \\
\hline Umbul Ngabean & 194 & Kota & Kolonial & Objek wisata \\
\hline Umbul Pengilon & 367 & Kota & Kolonial & Objek wisata \\
\hline Waduk & 167 & Ngemplak & Kolonial & Objek wisata dan \\
pengairan
\end{tabular}

Namun, yang mencengangkan adalah terekamnya 31 data arkeologi di lereng timur Gunung Merapi (dan Merbabu) yang terbengkelai dan sangat kontras dengan nilai luhur yang terkandung di dalamnya. Data arkeologi yang "terlantar" tersebut adalah:

\begin{tabular}{|c|c|c|c|c|}
\hline OBJEK & ELEV & KEC & MASA & PEMANFAATAN \\
\hline Kompleks Makam Belanda & 692 & Ampel & Kolonial & Terbengkalai. \\
\hline $\begin{array}{c}\text { Pesanggrahan } \\
\text { Pracimoharjo }\end{array}$ & 794 & Cepogo & Islam & $\begin{array}{c}\text { Terbengkalai, } \\
\text { namun ada bagian } \\
\text { tertentu yang } \\
\text { dimanfaatkan } \\
\text { untuk tempat } \\
\text { bersemadi }\end{array}$ \\
\hline Arca Durga & 998 & Cepogo & Klasik & Terbengkelai \\
\hline Batu Cadi & 947 & Cepogo & Klasik & Terbengkelai \\
\hline Batu Candi & 925 & Cepogo & Klasik & Terbengkelai \\
\hline Batu Candi & 931 & Cepogo & Klasik & Terbengkelai \\
\hline Batu Candi & 932 & Cepogo & Klasik & Terbengkelai \\
\hline Candi Lawang & 932 & Cepogo & Klasik & tidak ada \\
\hline Lumpang Batu & 998 & Cepogo & Klasik & Terbengkelai \\
\hline
\end{tabular}




\begin{tabular}{|c|c|c|c|c|}
\hline $\begin{array}{c}\text { Sumur Kuna } 901 \text { (Sumur } \\
\text { Songo) }\end{array}$ & 621 & Cepogo & Klasik & Terbengkelai \\
\hline $\begin{array}{l}\text { Sumur Kuna } 902 \text { (Sumur } \\
\text { Songo) }\end{array}$ & 623 & Cepogo & Klasik & Terbengkelai \\
\hline $\begin{array}{c}\text { Sumur Kuna } 903 \text { (Sumur } \\
\text { Songo) }\end{array}$ & 636 & Cepogo & Klasik & Terbengkelai \\
\hline $\begin{array}{c}\text { Sumur Kuna } 904 \text { (Sumur } \\
\text { Songo) }\end{array}$ & 634 & Cepogo & Klasik & Terbengkelai \\
\hline Gua Jepang 3 & 296 & Klego & Kolonial & $\begin{array}{c}\text { Tidak } \\
\text { dimanfaatkan. }\end{array}$ \\
\hline Gua Jepang 4 & 310 & Klego & Kolonial & $\begin{array}{c}\text { Tidak } \\
\text { dimanfaatkan. }\end{array}$ \\
\hline Gua Jepang 5 & 316 & Klego & Kolonial & $\begin{array}{c}\text { Tidak } \\
\text { dimanfaatkan. }\end{array}$ \\
\hline Rumah tinggal & 428 & Kota & Kolonial & $\begin{array}{c}\text { Tidak } \\
\text { dimanfaatkan / } \\
\text { terbengkalai }\end{array}$ \\
\hline Rumah Tinggal & 454 & Kota & Kolonial & $\begin{array}{c}\text { Rumah tinggal, } \\
\text { tetapi kosong / } \\
\text { tidak dihuni }\end{array}$ \\
\hline Arca Dhyanibuddha & 311 & Mojosongo & Klasik & $\begin{array}{c}\text { Disimpan di Kantor } \\
\text { Kecamatan } \\
\text { Mojosongo } \\
\end{array}$ \\
\hline Arca Kuwera (Slembi 3) & 399 & Mojosongo & Klasik & $\begin{array}{c}\text { Disimpan di rumah } \\
\text { penduduk }\end{array}$ \\
\hline Batu Candi (Recosari 1) & 406 & Mojosongo & Klasik & Terbengkalai \\
\hline $\begin{array}{l}\text { Lumpang Batu } \\
\text { (Karangkidul 2) }\end{array}$ & 351 & Mojosongo & Klasik & $\begin{array}{c}\text { Sudah tidak } \\
\text { dipergunakan lagi }\end{array}$ \\
\hline Lumpang Batu (Magersari) & 405 & Mojosongo & Klasik & $\begin{array}{c}\text { Sudah tidak } \\
\text { dipergunakan lagi }\end{array}$ \\
\hline $\begin{array}{l}\text { Lumpang Batu (Recosari } \\
\text { 2) }\end{array}$ & 405 & Mojosongo & Klasik & $\begin{array}{c}\text { Sudah tidak } \\
\text { dipergunakan lagi }\end{array}$ \\
\hline Lumpang Batu (Slembi 1) & 406 & Mojosongo & Klasik & $\begin{array}{c}\text { Sudah tidak } \\
\text { dipergunakan lagi }\end{array}$ \\
\hline Lumpang Batu (Slembi 2) & 403 & Mojosongo & Klasik & $\begin{array}{c}\text { Sudah tidak } \\
\text { dipergunakan lagi }\end{array}$ \\
\hline Batu Candi (Karangrejo 1) & 597 & Musuk & Klasik & Terbengkalai \\
\hline Batu Candi (Karangrejo 3) & 599 & Musuk & Klasik & $\begin{array}{l}\text { talud dan batas } \\
\text { pekarangan }\end{array}$ \\
\hline Batu Candi (Kebongulo) & 601 & Musuk & Klasik & $\begin{array}{l}\text { talud dan batas } \\
\text { pekarangan }\end{array}$ \\
\hline Yoni (Karangrejo 2) & 598 & Musuk & Klasik & Terbengkalai \\
\hline Yoni (Sukorame) & 565 & Musuk & Klasik & Terbengkalai \\
\hline
\end{tabular}

\section{B. Gejala Potensi Pengembangan Penelitian}

Data Arkeologi yang tersebar di Kabupaten Boyolali secara akadmik berada di dalam kerangka masa klasik hingga masa kolonial. Gambaran kedua rentang masa tersebut setidaknya dapat dikaitkan dengan masa Mataram Kuna hingga masa pengaruh Eropa dan pendudukan Jepang. 
Nama Mataram sebenamya baru muncul sekitar awal abad VIII M, yaitu saat Sanjaya berkuasa. Sanjaya menyebut dirinya sebagai Rakai Mataram Sang Ratu Sanjaya. Namun leluhurnya sudah mulai memerintah di Jawa Tengah sejak abad VII M yang diawali oleh Dapunta Selendra sebagai pendiri wangsa Çailendra. Adapun nama kerajaannya hingga saat ini belum diketahui karena tidak/ belum ditemukan prasasti yang menyebutkan hal itu. Pada abad V M berita-berita Cina dari jaman dinasti Sung Awal (420-470 M) menyebut Jawa dengan sebutan She-p'o, kemudian berubah menjadi Holing pada masa dinasti T'ang (618-906 $\mathrm{M})$ dan berlangsung hingga tahun $818 \mathrm{M}$, selanjutnya berubah lagi menjadi She-po sejak tahun 820 sampai 856 M (Damais, 1964: 140-141; Poesponegoro, 1984: 93).

Di masa yang lebih muda bangsa-bangsa Barat khususnya Portugis dan Belanda, sekitar abad ke-16 dan abad ke-17 M datang ke Indonesia. Pada awalnya kedatangan mereka didorong oleh kepentingan ekonomik, khususnya dalam menguasai sumberdaya alam. Namun dalam perkembangannya berubah menjadi kepentingan politik, dari sebelumnya sifat hubungan dalam rangka perdagangan menjadi nafsu untuk untuk menguasai wilayah keseluruhan (Abbas, 1998/1999: 1). Perubahan itu dimulai dengan penaklukan Batavia pada tahun 1619 hingga akhirnya sebagian besar wilayah Jawa takluk pada tahun 1830 (Lombard, 1996: 105). Luasnya wilayah Jawa yang takluk secara militer dan bahkan politik, berpengaruh juga pada aspek lainnya, terutama ekonomi dan juga anasir budaya, sebagaimana terlihat pada bangunan-banguan bergaya Eropa. Pengaruh ini sedemikan luas, tak kecuali wilayah Boyolali di lereng timur Merapi.

Selanjutnya, di masa yang lebih kemudian, yaitu sekitar kurun perang dunia ke-2 (PD II) kekuatan lain masuk ke Indonesia, termasuk di kabupaten Boyolali, yaitu kekuatan militer Jepang. Meskipun dalam jangka waktu yang relatif pendek, namun pengaruh kehadiran Jepang juga telah mewarnai rona lereng timur Merapi sebagai sebuah kawasan budaya. Jejak kehadiran kekuatan Jepang tersebut antara lain tercermin dari tinggalan berupa gua-gua yang dibuat oleh tentara Jepang sebagai salah satu sarana pertahanan militer.

Terlepas dari beragamnya karakter data arkeologi di Boyolali serta ketidakseimbangan perhatian yang diberikan kepada warisan leluhur, secara umum kawasan ini secara akademik sesungguhnya memiliki potensi yang sangat besar untuk digali kandungan nilai dan maknanya demi berbagai kepentingan. Namun demikian, berdasarkan pengamatan dan pertimbangan potensi akdemik serta kandungan nilai ilmiah yang ada, sedikitnya terdapat 3 titik potensi yang dirasa paling mendesak untuk ditindaklanjuti dengan penelitian pendalaman, baik melalui penelitian arkeologi, cultural resources management, maupun disiplin lain yang terkait. Penelitian pendalaman ini dimaksudkan untuk mendapatkan informasi yang komprehensif atas situs-situs tersebut yang nantinya dapat digunakan sebagai bahan dan kerangka dalam program pengembangan yang lebih luas, termasuk pengelolaan dan pemanfaatannya. 
Ketiga situs tersebut adalah (Tim Penelitian Balai Arkeologi Yogyakarta, 2010):

\section{1) Situs Candi Lawang}

Situs ini sudah berada dalam program pelestarian di bawah BP3 Jawa Tengah, dan bahkan telah dilakukan pemugaran berdasarkan komponen bangunan yang ada. Tahun 2007, Pemerintah Daerah Kabupaten Boyolali bekerja sama dengan Balai Arkeologi Yogyakarta melaksanakan penelitian di Candi Lawang guna mengungkap aspek-aspek yang belum terungkap.

Hasil penelitian tersebut antara lain berhasil mengungkap keberadaan tembok pagar, karakter Candi Lawang, serta permasalahan dan arah pengembangan situs ini (Tim Penelitian Balai Arkeologi Yogyakarta, 2007). Di samping aspek-aspek yang berhasil diungkapkan, penelitian ini juga membuahkan beberapa pertanyaan penting untuk diungkapkan, seperti kejelasan tentang keberadaan tembok pagar candi, gambaran kontekstual dengan data arkeologi di sekitarnya, serta konsep dan arah pengembangan situs sebagai data arkeologi yang bermanfaat.

\section{2) Situs Masa Klasik di Desa Sukorame, Kecamatan Musuk}

Di wilayah ini terdapat 2 spot data arkeologi yang secara akademik sangat potensial untuk dikembangkan penelitian arkeologi sebagai dasar pengembangan dan pemanfaatan, yaitu (Tim Penelitian Balai Arkeologi Yogyakarta, 2010):

Spot 1: terdiri atas 3 titik potensi yang diduga kuat saling terkait sebagai sebuah situs bangunan candi yang cukup besar. Hal ini didasarkan pada kedekatan ketiga titik serta ukuran komponen bangunan candi dan yoni yang ditemukan, namun masih terbengkelai. Ketiga titik dalam spot 1 adalah:

\section{a. Situs Karangrejo 1}

Situs Karangrejo 1 yang berada di Musuk, Desa Sukorame, Dusun Karangrejo merupakan kumpulan batu-batu candi yang ditemukan di sekitar Balai Desa Sukorame. Batu-batu candi tersebut sekarang dikumpulkan di sebelah barat Balai Desa Sukorame. Batu-batu candi yang dijumpai sangatlah bervariasi, yaitu batu candi yang berprofil seperti kemuncak, batu sudut, antefik. Situs yang termasuk dalam masa klasik ini berada pada ketinggian $597 \mathrm{dpl}$ dan berada di area Balai Desa Sukorame. Berdasarkan kedekatan lokasinya, diduga situs Karangrejo 1 merupakan satu konteks dengan situs Karangrejo 2 dan situs Karangrejo 3 


\section{b. Situs Karangrejo 2}

Situs Karangrejo 2 merupakan sebuah yoni yang relatif utuh dan mempunyai ukuran yang relatif besar, dengan ukuran bagian bawah sekitar 1 meter. Keberadaan Yoni ini sekarang masih dapat dijumpai berada di belakang Balai Desa Sukorame. Yoni yang menggunakan bahan batu andesit ini hanya bagian ceratnya yang sudah tidak utuh lagi (patah). Ukuran Yoni bagian atas $77 \times 77 \mathrm{~cm}$, bagian bawah $107 \times 107 \mathrm{~cm}$, dengan tinggi $89 \mathrm{~cm}$. Pada bagian tengah yoni terdapat lubang berbentuk segi empat dengan ukuran $28 \times 28 \mathrm{~cm}$ dan kedalaman $42 \mathrm{~cm}$.

Secara administrasi, situs Karangrejo 2 berada di wilayah Kecamatan Musuk, Desa Sukorame, Dusun Karangrejo. Berdasarkan lokasinya, situs Karangrejo 2 yang berada di lahan miliki Bapak Misman ini diduga kuat masih mempunyai keterkaitan dengan situs Karangrejo 1 dan situs Karangrejo 3.

\section{c. Situs Karangrejo 3}

Situs Karangrejo 3 berupa situs temuan batu-batu candi yang keberadaannya tidak jauh dari Situs Karangrejo 1 dan Karangrejo 2. Batubatu candi tersebut sekarang dimanfaatkan sebagai talud pembatas pekarangan. Ukuran batu candi tersebut panjang $35-60 \mathrm{~cm}$, lebar $34-45$ $\mathrm{cm}$, namun tebal batu tidak diketahui karena posisi batu tertanam di dalam tanah.

Berdasarkan lokasinya yang berdekatan, keberadaan situs Karangrejo 1, 2, 3 saling berdekatan dan diduga masih mempunyai keterkaitan satu dengan yang lainnya. Berdasarkan hasil pengamatan di lapangan situs-situs tersebut berpotensi dilakukan penelitian lanjutan berupa ekskavasi penelitian untuk memperoleh data mengenai keberadaan bangunan candi di lokasi tersebut.
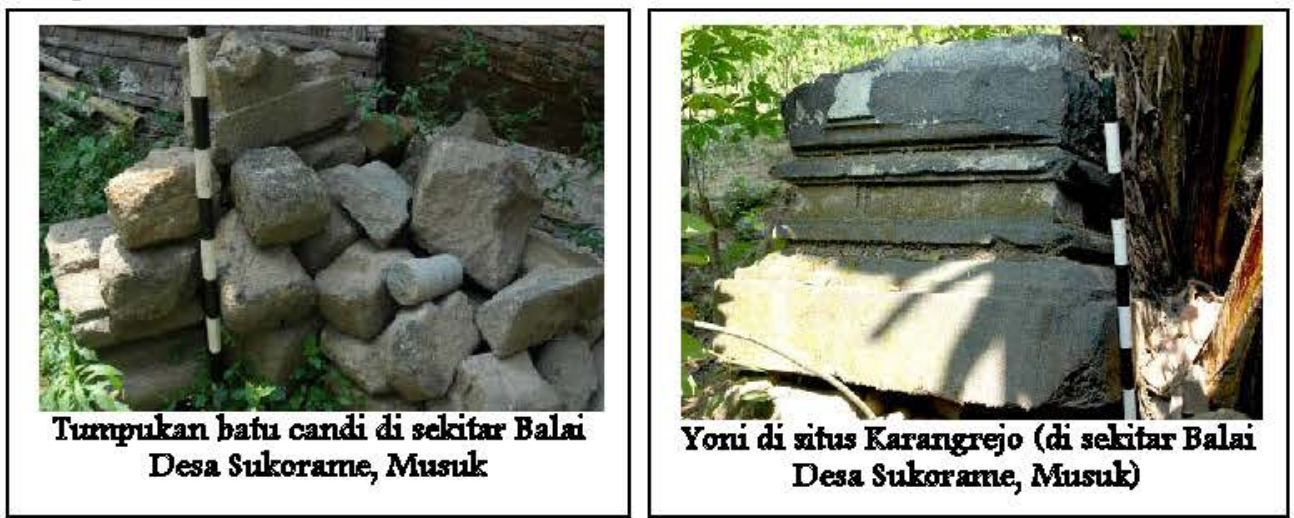

Spot 2: terdiri atas 2 buah yoni dan sebuah hamparan lahan terkupas dan di permukaannya ditemukan artefak cukup padat. Dari artefak yang ditemukan, antara lain berupa fragmen keramik di antaranya berasal dari Cina masa Dinasti T'ang, abad VIII masehi. Artefak lain berupa pecahan tembikar yang diduga kuat semasa dengan pecahan keramik T'ang, sehingga keberadaan dua buah yoni di area ini kemungkinan berada 
dalam satu konteks. Penelitian pendalaman sangat diperlukan, antara lain guna mengungkap karakter situs ini yang secara hipotetik merupakan situs permukiman masa klasik.

Di situs Sukorame dijumpai dua buah yoni yang tergeletak di pinggir jalan desa Sukorame dan di lapangan desa Sukorame. Yoni-yoni yang terbuat dari batu andesit tersebut kondisinya terancam kerusakan maupun hilang. Yoni yang terletak di lapangan Desa Sukorame, pada bagian atasnya mempunyai ukuran $88 \times 88 \mathrm{~cm}$ dengan tinggi $95 \mathrm{~cm}$, lubang bagian atas berbentuk persegi dengan ukuran $26 \times 26 \mathrm{~cm}$ dengan kedalaman 56 $\mathrm{cm}$. Situs yang berada di lapangan Sukorame ini termasuk ke dalam wilayah Kecamatan Musuk, Desa Sukorame, Dusun Sukorame. Selain itu, di sekitar situs Sukorame pada saat dilakukan survei dijumpai beberapa temuan artefak berupa fragmen gerabah, fragmen keramik, serta gumpalan yang diduga berupa terak besi.
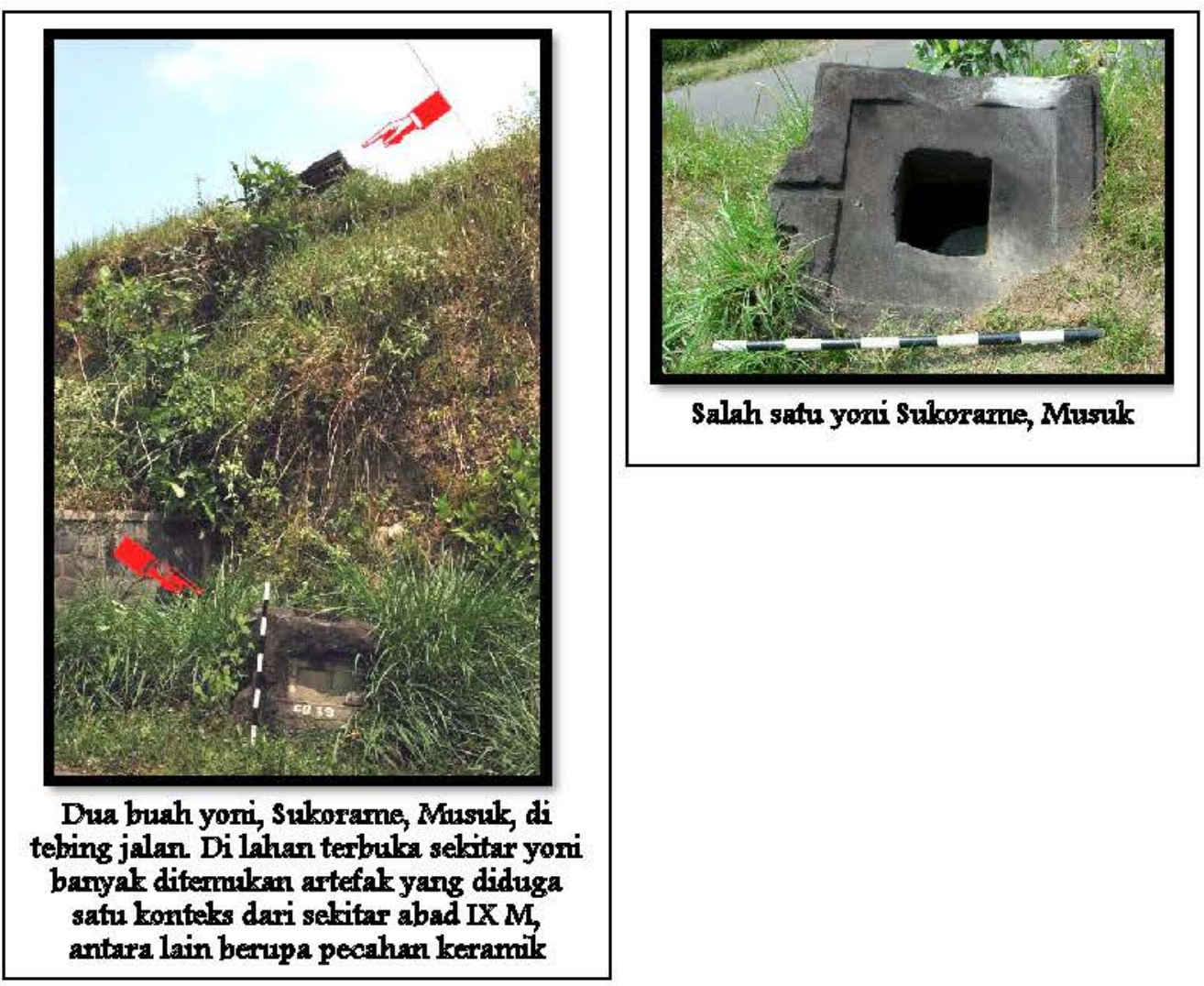


\section{PENUTUP}

Data arkeologi berhasil didata sejumlah 79 titik potensi yang tersebar di 11 wilayah kecamatan yang terdiri atas 39 lokasi potensial dari masa klasik, 13 lokasi dari masa islam, dan 27 lokasi dari masa kolonial. Data sebaran keruangan yang berada pada ketinggian antara 150 - 300 mdpl terdiri atas 21 titik potensi dengan rincian berdasarkan masa adalah: 7 lokasi dari masa klasik, 9 lokasi potensi dari masa islam, dan 5 titik dari masa kolonial. Berdasarkan ketinggian antara 301 - 500 mdpl terdapat 31 lokasi data arkeologi yang terdiri atas 9 situs masa klasik, 1 situs masa islam, dan 21 situs masa kolonial. Data arkeologi yang berada pada ketinggian antara $501-800 \mathrm{mdpl}$ berdasarkan masanya meliputi 18 lokasi potensi dengan rincian: 15 situs dan masa klasik, 2 situs dari masa islam, 1 lokasi dari masa kolonial. Sementara itu jumlah titik potensi data arkeologi yang berada pada ketinggian di atas $800 \mathrm{mdpl}$ adalah 9 lokasi, 8 situs diantaranya berasal dari masa klasik, dan 1 lainnya dari masa islam.

Data arkeologi yang berhasil direkam dalam eksplorasi arkeologis di lereng timur Gunung Merapi (dan Merbabu) secara umum sangat beragam, setidaknya meliputi 18 kategori. Dari masa klasik terdapat 7 kategori ragam dan karakter yang meliputi: arca, batu candi, candi, lumpang, petirtaan, sumur, dan yoni. Dari masa islam terdapat 4 kategori, yaitu makam, mesjid, pesanggrahan, dan umbul. Sementara itu, data arkeologi dari masa kolonial terdiri atas 9 kategori, yaitu: benteng, gereja, gua, kantor, makam, rumah, sekolah, umbul, dan waduk. Khusus masa islam dan kolonial, terdapat 2 kategori yang berlaku untuk kedua masa, yaitu makam dan umbul.

Keberadaan data arkeologi di Kabupaten Boyolali mencerminkan dinamika masa lalu yang sarat akan rona budaya dalam waktu yang cukup panjang, setidaknya sejak masa Mataram Kuna sekitar abad IX M hingga masa pendudukan Jepang. Namun, di sisi lain keberadaan bukti-bukti peradaban yang sedikit banyak telah ikut membentuk warna budaya di kawasan lereng timur Gunung Merapi dan Merbabu, khususnya di Kabupeten Boyolali, sebagian besar dalam keadaan terlantar. Berkaitan dengan hal itu, maka dalam aspek pengelolaan sangat diharapkan adanya tindak lanjut kegiatan berupa:

- eksplorasi data arkeologi yang lebih luas dan mendalam

- menyusun prioritas penanganan konservasi data arkeologi yang 'terlantar"

- penelitian arkeologi dengan prioritas di area Sukorame, Kecamatan Musuk 


\section{KEPUSTAKAAN}

Abbas, Novida. 1998/1999. Laporan Penelitian Arkeologi Sarana Pertahanan Kolonial. Balai Arkeologi Yogyakarta. Tidak Terbit.

Damais, L.C. 1964. La Transcription Chinoise Ho-ling Comme Designation de Java, BEFEO, LII, HLM. 93-141.

Lombard, Denys. 1996. Nusa Jawa: Silang Budaya - Batas-batas Pembaratan, I. Jakarta: PT Gramedia Pustaka Utama.

Poesponegoro, Marwati Djoened, dan Nugroho Notosusanto. 1984. Sejarah Nasional Indonesia II, Jakarta: P.N. Balai Pustaka.

Riyanto, Sugeng. 2006. "Identifikasi Pengelolaan Sumberdaya Arkeologi di Kabupaten Boyolali, Jawa Tengah" dalam Berita Penelitian Arkeologi No. 21. Yogyakarta: Balai Arkeologi Yogyakarta. HIm. 94-105

Tim Penelitian Balai Arkeologi Yogyakarta. 2007. "Candi Lawang: Rekonstruksi Masa Lalu dan Arah Pengembangannya". Laporan Penelitian Arkeologi. Tidak terbit.

Tim Penelitian Balai Arkeologi Yogyakarta. 2010. Eksplorasi Situs dan BCB di Kawasan Lereng Timur Gunung Merapi, Kabupaten Boyolali, Jawa Tengah". Laporan Penelitian Arkeologi. Tidak terbit. 